Available online at http://www.anpad.org.br/bar

\title{
Participant Diversity and Expressive Freedom in Firm-Managed and Customer-Managed Brand Communities
}

\author{
Stefânia Ordovás de Almeida \\ E-mail address: stefania.almeida@pucrs.br \\ Pontifícia Universidade do Rio Grande do Sul - PUCRS \\ PPGAd/FACE, Alameda Emílio de Menezes, 80/601, Porto Alegre, RS, 91340-360, Brazil. \\ José Afonso Mazzon \\ E-mail address: jamazzon@usp.br \\ Universidade de São Paulo - USP \\ PPGA/FEA, Av. Prof. Luciano Gualberto, 908, sala E-187, São Paulo, SP, 05508-010, Brazil. \\ Utpal Dholakia \\ E-mail address: dholakia@rice.edu \\ Rice Universtity \\ Jones Graduate School of Business, McNair Hall, Room 329, Houston, USA. \\ Hugo Müller Neto \\ E-mail address: hmullerneto@gmail.com \\ Universidade Federal do Rio Grande do Sul - UFRGS \\ PPGA/EA/UFRGS, Rua Washington Luiz, 855, Porto Alegre, RS, 90010-460, Brazil.
}

Received 12 June 2012; received in revised form 24 January 2013 (this paper has been with the authors for two revisions); accepted 30 January 2013; published online $1^{\text {st }}$ April 2013. 


\begin{abstract}
We examine differences between firm-managed and customer-managed brand communities with a conceptual model explaining how demographic and psychographic diversity of participants and their degree of expressive freedom engender trust, learning, and identification in the community, and affect firm-relevant outcomes. We test our hypotheses by estimating a structural equation model and conducting multiple sample analysis with survey data obtained from two leading XBOX brand communities in Brazil. Results reveal that greater demographic and psychographic diversity hinder learning and trust in the community's manager, but expressive freedom has a positive impact on identification with the community. The levels of expressive freedom and demographic diversity are lower yet their respective effects are stronger in the firm-managed community, whereas psychographic diversity is much less, but it has stronger negative effects, in the customer-managed community.
\end{abstract}

Key words: brand communities; participant diversity; expressive freedom; consumer behavior. 


\section{Introduction}

Brand communities, defined as "specialized non-geographically bound communities, based on a structured set of social relationships among admirers of a brand" (Muñiz \& O'Guinn, 2001, p. 412) are increasingly important, not only as conduits of information, places of social support, and channels of self-expression for consumers, but also as marketing programs for firms (e.g., Algesheimer \& Dholakia, 2006; Li \& Bernoff, 2008; McAlexander, Schouten, \& Koenig, 2002). One consequence of this increased interest is that popular brands often have many established brand communities, some organized and managed by the firm's professional marketing managers, and others that are grassroots organizations founded and run independently by customer enthusiasts (e.g., Dholakia, Blazevic, Wiertz, \& Algesheimer, 2009; Muñiz \& O’Guinn, 2001; Muñiz \& Schau, 2005; Porter \& Donthu, 2008; Weber, 2007).

As recent studies have made clear (e.g., Mathwick, Wiertz, \& de Ruyter, 2008; Porter \& Donthu, 2008), two important drivers of brand community success are to have the right participants in the community, and to encourage them to interact with one another in cordial and supportive ways that contribute to, rather than destroy, the brand's equity. For brand community managers, this involves answering key questions such as whether participant diversity along demographic and psychographic lines benefits or hurts community processes, and whether moderating participant discussions to keep them on-topic and free of extreme criticisms is an effective strategy (Li \& Bernoff, 2008; Weber, 2007). Understanding the impact of these variables on relevant outcomes for the brand community and the firm is also an important undertaking, these questions are equally pertinent to firm-managed and customer-managed brand community managers; yet, given the fundamental differences between the two, they are important to explore in each case. Prior studies on brand communities have not examined the effects of participants' demographic or psychographic diversity, or the impacts of their expressive freedom. Distinctions between firm-managed and customer-managed brand communities have also not been previously studied in the literature.

In this sense, in the present research, we seek to contribute to the brand community literature in two significant ways. First, we develop a conceptual framework which identifies two key decision variables for brand community managers upon which prior consumer research has not shed much light: (a) the demographic and psychographic diversity of the participant base, and (b) the degree of their expressive freedom. Our results reveal that greater participant diversity hinders learning and trust in the community's manager, but expressive freedom has a positive effect on the individual's identification with the community. We also examine effects of these variables on firm-relevant outcomes such as the individual's relationship with the brand, the community's influence on the person's buying decisions, trust in the firm, and oppositional loyalty.

Second, we examine moderating effects of the brand community's manager (i.e., whether the community is firm-managed or customer-managed) on mean levels of the key constructs in the conceptual framework and the strengths of the paths in it. Our objective in doing so is not only to understand similarities and differences between firm- and customer-managed brand communities, but also to provide specific insights to community managers when making decisions regarding participant diversity and expressive freedom. We find the levels of expressive freedom and demographic diversity to be lower in the firm-managed community, but psychographic diversity to be higher, when compared to the customer-managed community. Furthermore, the respective effects of demographic diversity and expressive freedom are stronger in the firm-managed community, whereas psychographic diversity has a stronger impact in the customer-managed community.

We tested our hypotheses through an empirical study conducted with 555 active participants of the two largest XBOX brand communities in Brazil, Portalxbox (consumer-managed) and XBOX Brasil (firm-managed). The videogame market was chosen based on factors such as user involvement and market representativeness. According to data from PricewaterhouseCoopers, in 2012 the global videogame industry should amount to US\$68 billion. In Brazil the situation is also promising, 
according to the German Company GFK Customer Research. Sales volumes have grown 53\% in 2011 as compared to 2010 , with 934,000 videogame consoles sold in retail. Total revenues were $\mathrm{R} \$ 650$ million for consoles and $\mathrm{R} \$ 320$ million for games in 2011. In fact, in Brazil more consoles have been sold than in Russia, France, Spain, Portugal and Switzerland.

In the next section, we present a conceptual framework that explains the effects of participant diversity and expressive freedom and is applicable to firm-managed and customer-managed brand communities. This is followed by a detailed consideration of the expected differences between the two communities.

\section{Proposed Conceptual Framework}

At the outset, it is important to note that we study managed brand communities in the sense that an individual or a group (firm employees or customers) is in charge of the community's functioning. The community's manager may perform such functions as registering and socializing new members; setting, monitoring, and enforcing community rules and policies; resolving disputes, moderating discussions, organizing and conducting online and/or offline meetings and social events; providing assistance; starting new discussions and energizing old ones; and conducting research to ascertain participants' preferences and satisfaction with the community.

Our conceptual framework, with its dimensions and relationships, is based on the seminal works done by Bagozzi and Dholakia (2002), Cova and Cova (2002), Dholakia, Bagozzi and Pearo (2004), Algesheimer, Dholakia and Herrmann (2005) and Bagozzi and Dholakia (2006a, 2006b). An analysis of those models, along with an in-depth literature review and extensive qualitative research, provided insights into new research opportunities and gaps to be filled in, as the introduction of three new dimensions never used before in consumer behavior or marketing frameworks: demographic diversity, psychographic diversity and expressive freedom. A brief description of the baseline studies and the paper's main contributions to consumer research through these new dimensions are in Table 1 below.

Table 1

Contributions from the Proposed New Dimensions to Consumer Research

\begin{tabular}{|c|c|c|}
\hline & Previous Studies & $\begin{array}{l}\text { New Contributions from the } \\
\text { Proposed Framework }\end{array}$ \\
\hline 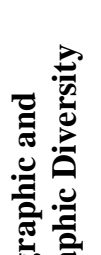 & $\begin{array}{l}\text { Diversity or similarity between consumers has } \\
\text { not been studied previously, but some previous } \\
\text { research analyzed similarity in work teams from } \\
\text { a sociological point of view (DiTomaso, Post, \& } \\
\text { Parks-Yancy, 2007; Zellmer-Bruhn, Maloney, } \\
\text { Bhappu, \& Rommel, 2008). }\end{array}$ & $\begin{array}{l}\text { - No previous field study is known by the authors in } \\
\text { which researchers have examined the effects of } \\
\text { demographic or psychographic diversity in the } \\
\text { field of consumer research or virtual communities. } \\
\text { In this sense, this is a contribution from the } \\
\text { proposed framework and study. }\end{array}$ \\
\hline 至 & $\begin{array}{l}\text { Cova and Cova (2002) studied characteristics of } \\
\text { consumer tribes as groups of demographically } \\
\text { heterogeneous people, though with a common } \\
\text { interest. }\end{array}$ & $\begin{array}{l}\text { The projected relationships between those two } \\
\text { dimensions and the other constructs in the model } \\
\text { also represent a new proposition and contribution. }\end{array}$ \\
\hline
\end{tabular}


Table 1 (continued)

\begin{tabular}{|c|c|c|}
\hline & Previous Studies & $\begin{array}{l}\text { New Contributions from the } \\
\text { Proposed Framework }\end{array}$ \\
\hline 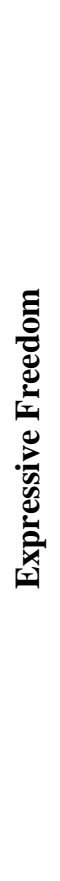 & $\begin{array}{l}\text { Bagozzi and Dholakia (2002) and Dholakia et al. } \\
\text { (2004) have already mentioned that the group, } \\
\text { rather than the product, should be nurtured in } \\
\text { consumer communities in order to make them } \\
\text { flourish. The hedonic, not the utilitarian, focus } \\
\text { should be the main reason for interaction in } \\
\text { consumer communities (Bagozzi, Dholakia, \& } \\
\text { Pearo, 2007). } \\
\text { - For Cova and Cova (2002), although some } \\
\text { passion or interest is vital for a brand community } \\
\text { to exist, this is not necessarily the only reason for } \\
\text { interaction among its members; the explanation } \\
\text { goes beyond the instrumental brand or product } \\
\text { usage. } \\
\text { Another research topic related to expressive } \\
\text { freedom already discussed is the community } \\
\text { usage rules. Those rules define the amount of } \\
\text { freedom given to participants so that control over } \\
\text { communication doesn't create a bad image for the } \\
\text { community (e.g.: Berthon et al., 2008; Muñiz \& } \\
\text { Schau, 2007; Ridings, Gefen, \& Arinze, 2002). }\end{array}$ & $\begin{array}{l}\text { Despite the already mentioned studies discussing } \\
\text { the importance of expressive freedom in the } \\
\text { specific context of virtual consumer communities, } \\
\text { there is no information on any previous study } \\
\text { using this dimension as a construct in a theoretical } \\
\text { framework as proposed here. } \\
\text { The proposed theoretical framework also aims to } \\
\text { understand the relationship between expressive } \\
\text { freedom and its consequent dimensions. }\end{array}$ \\
\hline
\end{tabular}

The best starting point for presenting our proposed conceptual framework is an introduction of its three mediating variables: trust in the community's manager, learning, and community identification. These mediators have been established as important predictors in explaining participation in brand communities by prior research (e.g., Algesheimer, Dholakia, \& Herrmann, 2005; Dholakia et al., 2009; Mathwick et al., 2008; McAlexander et al., 2002; Porter \& Donthu, 2008).

The theoretical proposed model is presented in Figure 1.

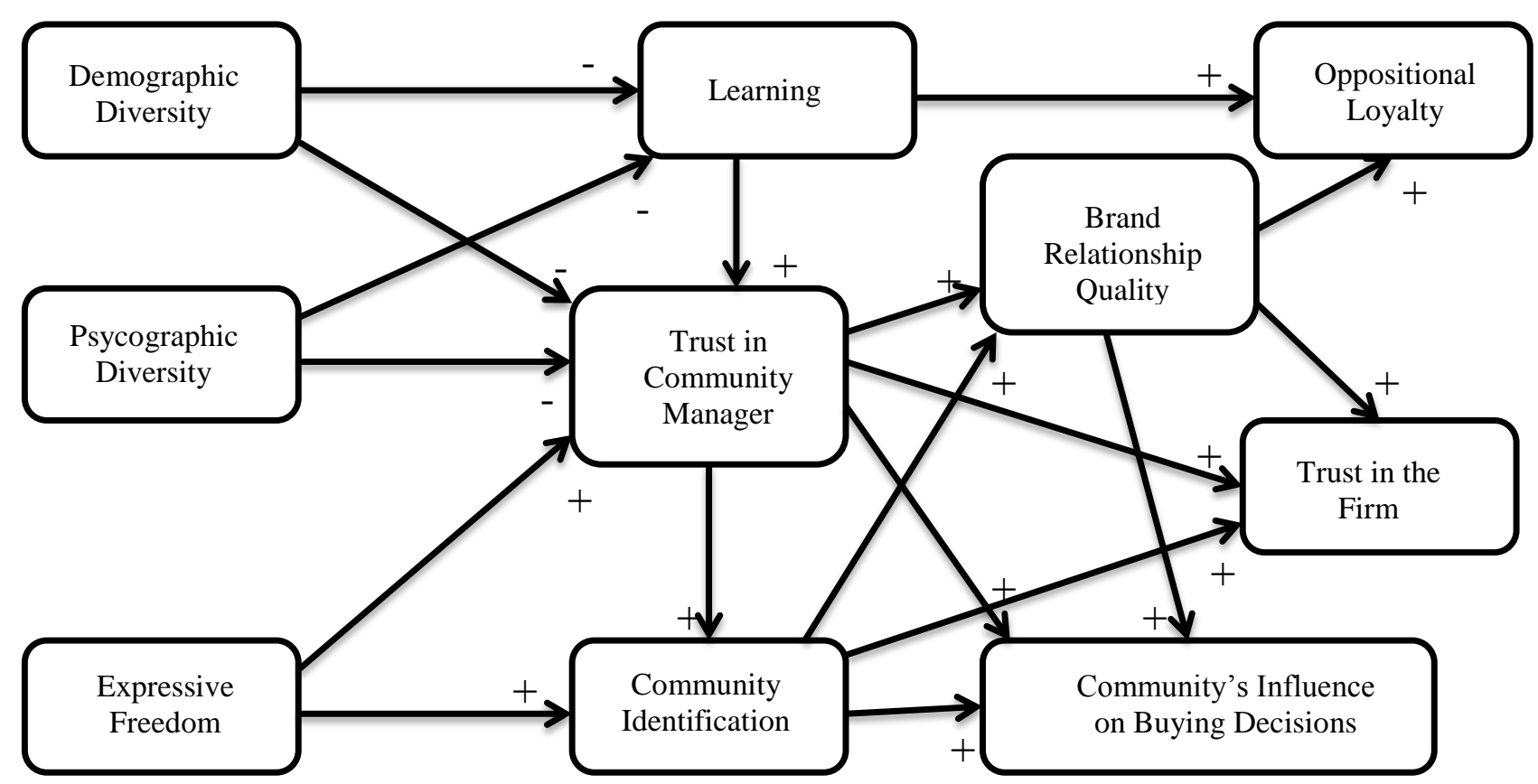

Figure 1. Theoretical Framework. 
Trust in the community manager. Current marketing thinking regards trust as essential for building meaningful relationships with customers (e.g., Agustin \& Singh, 2005; Palmatier, Dant, Grewal, \& Evans, 2006). We include two trust constructs in our conceptual framework: trust in the community manager and trust in the firm (described later). Greater trust points out to the belief that the manager will keep the community avenues running and available to its users, and consonant to the community's norms and rules. It also entails the view that the manager will rely on ethical principles in making decisions regarding the community (Porter \& Donthu, 2008; Ridings, Gefen, \& Arinze, 2002). Trust in the community manager is an important mediating variable because of the risks and uncertainties inherent in brand community interactions, stemming from the anonymity afforded to participants, and the difficulties associated with discerning the motives of the community's manager (Mathwick et al., 2008; Ridings et al., 2002).

Learning. Learning is defined by the authors as the participants' perceptions of having acquired new knowledge about the product category from the brand community. For many products, customers must learn continuously to keep abreast of new developments in the product category. Brand communities provide learning through education and service support (Dholakia et al., 2009; Mathwick et al., 2008). Research has shown that participants share knowledge in brand communities vicariously and interactively, often including contextual details (Dholakia et al., 2009). Learning is an important mediating variable in our conceptual framework because it is dictated by community characteristics, and it shapes subsequent cognitive and behavioral responses of participants (Dholakia et al., 2009), regardless of whether the individual looking for information perceives him/herself as being experienced or knowledgeable about the product (Adjei, Noble, \& Noble, 2010).

In our framework, a stronger learning perception is expected to affect trust in the community manager positively, by contributing to beliefs in his or her benevolence and reliability, and adding to the perception that valuable information is gained from participating in the community (Porter \& Donthu, 2008). Thus, we hypothesize:

H1: Greater learning leads to greater trust in the community manager.

Community identification. The third mediator in our conceptual framework is community identification, which prior research has found to be an important driver of participation (e.g., Algesheimer et al., 2005). Community identification draws upon self-categorization theory (e.g., Turner, 1987) and social identity theory (e.g., Tajfel \& Turner, 1986), which suggest that a categorization process is used by individuals to derive a valued self-identity, which in turn enhances self-identity and satisfies the drive for positive self-esteem.

Consistent with Algesheimer et al. (2005), we define community identification as the degree to which the participant categorizes himself or herself as a member of the brand community. A higher degree of community identification implies that the participant places greater value on his or her identity as a brand community member (Algesheimer et al., 2005). One driver of community identification in our framework is trust in the community manager. Therefore, we hypothesize:

H2: Greater trust in the community manager leads to greater community identification.

Demographic and psychographic diversity. Even though its participants are united in their interest in the brand, to say that a brand community is diverse is to recognize other qualitative or categorical distinctions among them that are evident to its participants (DiTomaso, Post, \& ParksYancy, 2007). One important objective of this research is to examine the effects of demographic and psychographic diversity of brand community participants. To this end, we define demographic diversity as participants' perceptions of the extent to which other members are different from them in age, income, gender, and profession, and psychographic diversity as participants' perceptions of the extent to which other members are different from them in their values, interests, and hobbies.

A large body of organizational and sociological research on work teams and workplace diversity (e.g., McKay \& McDaniel, 2006) provides useful insights on the roles of participant diversity in brand communities. This research has found that group composition, defined in terms of salient and 
symbolically meaningful demographic and cultural characteristics, is one of the most important variables influencing group processes as well as individual perceptions and behavior in a group setting. We expect negative effects of participant diversity to be more relevant to the brand community setting where community members seldom make decisions as a group, but communicate and share information with one another frequently. As a result, higher levels of perceived demographic and psychographic diversity are expected to adversely affect sharing product knowledge by community participants, thus hindering learning.

In brand communities, it is very common for managers to put in place ways to confer status on participants based on the amount of their contributions (e.g., Dholakia et al., 2009; Mathwick et al., 2008). Thus motivated, many members participate actively, sometimes even to their personal detriment, in order to rise in status within the community. Then they use their high status to exert influence on the community's functioning as well as on other members (Algesheimer et al., 2005). As a consequence, other participants may view these efforts in negative ways, casting doubts on the status seekers', and the community manager's, motives (e.g., Donath, 1999), leading to a loss of trust in the community and its manager. Thus, demographic and psychographic diversity are likely to affect trust in the community manager adversely. Based on this discussion, our hypotheses are:

H3: Greater demographic diversity leads to (a) lower trust in community manager and (b) lower learning.

H4: Greater psychographic diversity leads to (a) lower trust in community manager and (b) lower learning.

Expressive freedom. We define expressive freedom as the participants' perceptions of being able to discuss any topic of interest without restrictions by the community manager. These perceptions are directly influenced by the community manager's stated policies and enforcement actions. The question of how much expressive freedom to give participants is especially relevant because prior studies have found that many brand community participants are openly critical of the firm's marketing programs (Muñiz \& O'Guinn, 2001; Muñiz \& Schau, 2007). Likewise, research has shown that communication in many virtual communities tends to be uninhibited and blunt, with participants expressing extreme views and using aggressive language (Muñiz \& Hamer, 2001).

Results from Adjei, Noble and Noble (2010) proves that the quality of the information exchanged by consumers in a brand community reduces the level of uncertainty related to the brand and its products, as well as contributes to increase profits, through the number of items purchased, as well as the number of categories purchased from the firm. In this sense, according to the authors, community managers should try to enhance communication levels in all aspects, including frequency and duration.

Prior research on virtual communities provides guidance, indicating that censoring participants comes at a price. Repeated attempts to control the flow of conversation can lead to questioning of the manager's motives, and the belief that they are being deceived (Donath, 1999), which in turn diminishes beliefs on the manager's benevolence and integrity, and lowers trust perceptions (Ridings et al., 2002). Moreover, controlling communications content also creates an unfavorable image of the brand community as a social group, generating a mismatch between one's own self-identity and the group's identity, and reducing the individual's identification with the community. Lower levels of expressive freedom result in lower community identification and trust, and vice versa. Based on this discussion, our hypothesis is:

H5: Expressive freedom positively impacts (a) community identification and (b) trust in community manager.

Brand relationship quality. We examine four outcomes with managerial salience in the current research. The first one, brand relationship quality, captures relational aspects of the consumer's brand evaluation. Consistent with Algesheimer and colleagues (2005), we define it as the degree to which the brand community participant views the brand as a satisfactory partner in an ongoing relationship. It 
involves cognitive aspects, such as the degree to which the consumer believes that the brand's image overlaps with his or her self-image, and emotional elements such as the degree of the consumer's emotional attachment to the brand.

Additionally, research on trust perceptions has found that it engenders greater customer loyalty (Agustin \& Singh, 2005), increases purchase intentions (Schlosser, White, \& Lloyd, 2006), and mediates the effects of customer perceptions on customer-focused outcomes such as cooperation, expectation of continuity, and word-of-mouth (Morgan \& Hunt, 1994; Palmatier et al., 2006). The rationale for the impact of trust over loyalty rests also on the argument by Mitchell (1999) that lower levels of uncertainty lead to higher purchase intentions due to the fact that consumers try to minimize perceived risk when buying a product.

Trust perceptions act as an informational signal to many consumers (Schlosser et al., 2006), influencing their thinking and behavior, and leading them to reward firms that they trust by reciprocating and giving them more business (Agustin \& Singh, 2005). Consistent with this rationale, brand information access can help to enhance consumer confidence levels. In virtual brand communities, information and knowledge are achieved through interaction, which fosters brand confidence by increasing familiarity with the brand and the easiness in solving problems using branded products (Casaló, Flavián, \& Guinalíu, 2007). Moreover, consumers will see communities as avenues for support in using the products correctly due to the moral responsibility that exists among members of virtual communities (Flavián \& Guinalíu, 2005).

In the present case, we expect perceptions of trust in the community manager to work in a similar fashion by providing participants with meaningful information on the firm and by leading to a stronger relationship with its brand. Therefore, our hypothesis is:

H6: (a) Community identification and (b) trust in a community manager positively impact brand relationship quality.

Community's influence on buying decisions. This variable is defined as the impact of the community on the member's opinions and decisions regarding the product category. A number of brand community studies have shown that communities exert substantial influence on their members, by impacting their thoughts and actions (Algesheimer et al., 2005; Muñiz \& Hamer, 2001; Thompson \& Sinha, 2008). Consistent with research showing that individuals identifying with a particular group tend to imitate its members to reinforce the shared identity (e.g., Mackie, Devos, \& Smith, 2000), we expect the degree of the community's influence to be positively affected by community identification. We also expect that greater trust in the community manager will increase the community's influence on its participants (Porter \& Donthu, 2008). This prediction is also supported by prior virtual community research (Ridings et al., 2002), which has found that greater trust makes participants more willing to accept information from other community members.

Finally, we expect that, by increasing interest in the brand and raising the likelihood it will be considered and chosen on purchase occasions, a stronger brand relationship quality will lead to a greater influence by the community on the participant's buying decisions. Research form StokburgerSauer (2010) shows that a strong consumer-brand identification positively affects satisfaction, loyalty and word-of-mouth. This discussion is summarized in the following hypothesis:

H7: (a) Community identification, (b) trust in the community manager, and (c) brand relationship quality positively impact community's influence on buying decisions.

Trust in firm. Trust in the firm is an important outcome from a managerial standpoint not only because it creates a relationship that is highly valued by the customer (Morgan \& Hunt, 1994), extending beyond the interactions with the community, but also because it has been linked directly to organizational performance (e.g., Davis, Schoorman, Mayer, \& Tan, 2000).

We expect trust in the firm to be affected by community identification because the shared consciousness inherent in greater social identification is likely to support stronger convictions about 
the firm's intentions and integrity, leading to greater trust in it. This reasoning is consistent with the commitment-trust theory which posits that shared values between partners positively affect their trust perceptions (Morgan \& Hunt, 1994). Second, trust in the brand community manager is also expected to be contributory to trust in the firm. This is because the beliefs in the brand community manager's benevolence, reliability, and integrity, along with discussions among the trusted community regarding the firm's products and brands, are likely to elevate participant beliefs in the firm's good intentions and reliability, leading to greater trust in it. Finally, community members' relationship with the brand is likely to have a significant positive impact on trust in the firm. Therefore:

H8: (a) Community identification, (b) trust in community manager, and (c) brand relationship quality positively impact trust in the firm.

Oppositional brand loyalty. Prior research has shown that brand communities strengthen a member's devotion and loyalty to the brand (Algesheimer et al., 2005; McAlexander et al., 2002). For many loyal customers, an important facet of loyalty is derived from explicitly developing negative perceptions of competing brands. Oppositional brand loyalty, which is defined by the authors as "the participant's perception that competing brands are inferior to the target brand and should be avoided", benefits the firm by reducing the likelihood that members will purchase competing brand products (Muñiz \& Hamer, 2001; Thompson \& Sinha, 2008) and strengthens the possibility of future purchases of the firm's brand.

For the community participant, the tendency to position the brand against the competition arises from the perception that he/she is being threatened, along with a desire to help the target brand to maintain its superiority over the competition (Muñiz \& Schau, 2007). Such an adversarial position is fostered by the perceived normative pressure to conform to the brand community's views (Algesheimer et al., 2005) and to signal this inclination to conformity by seeking to dissociate from disfavored brands through means that are visible to the community. The stronger a participant's relationship with the target brand, the more pronounced these tendencies will be (Mackie et al., 2000). Based on this reasoning, brand relationship quality is predicted to impact oppositional brand loyalty positively in our conceptual framework.

We also expect greater learning to increase this tendency by giving community participants more reasons to choose the target brand over the competing brands. It should also make participants more confident and willing to formulate and express their adversarial views (Koriat, 1993). Therefore, we predict a positive impact of learning on oppositional loyalty.

H9: (a) Perceived increase in learning and (b) brand relationship quality positively impact oppositional brand loyalty.

Differences between Firm-Managed and Customer-Managed Brand Communities. In this section, we examine the role of the community's manager in moderating the effects of participant diversity and expressive freedom in our proposed conceptual framework. Whether the firm or its customers organize and manage the community is a fundamental dimension on which brand communities vary. As we will discuss in detail, firm- and customer-managed communities differ in significant ways. However, they also share some common aspects, besides being effective tools in influencing sales (Adjei et al., 2010). First, both brand communities are comprised of customers who are brand fans. Some participants may even have overlapping memberships within the two communities. Second, participants in both communities are interested in the same subject matter, namely news and information about the brand and its competitors.

There are also several significant differences between firm-managed and customer-managed brand communities. Ouwersloot and Odekerken-Schröder (2008) point out that brand community members constitute a specific customer group, but treating them as homogeneous could be a serious mistake, because they differ in so many aspects. Perhaps the most important distinction has to do with the community manager's motives. Firms offer their customers brand communities to accomplish marketing objectives (Li \& Bernoff, 2008; Weber, 2007). Some firms use brand communities to gather 
market research insights by monitoring discussions and/or interacting with participants (e.g., Kozinets, 2006). Others do so to increase participants' loyalty to their products and brands (McAlexander et al., 2002), and to increase their purchase behaviors (e.g., Algesheimer \& Dholakia, 2006). Consequently, customers are recruited to join in the community through targeted approaches, and the facilities and affordances provided to participants are designed to reach those objectives. It is not uncommon for firms to use established segmentation variables, particularly demographic, to recruit community participants (e.g. Weber, 2007).

In contrast, customer-managed communities rarely have specific marketing goals. Instead, the community managers seek to express their love and admiration for the brand through organizing and managing the community. Participants, too, self-select and join the customer-managed community because of a shared passion for the brand, which often overlaps with common values, hobbies, and lifestyles (e.g., Muñiz \& Schau, 2005; Schouten \& McAlexander, 1995). These differences suggest that customers in firm-managed communities should be more similar to each other in demographic characteristics, and those in customer-managed communities should be more likely to share psychographic commonalities.

The second difference between the two communities has to do with managers' constraints in the two cases. As noted earlier, professional managers of firm-managed communities are dictated by the firm's marketing objectives and strive for consistency with its other marketing programs. Consequently, their emphasis is on a fit between the tone and content of community members communications and the other marketing communications being sent by the firm (Weber, 2007). In this sense, managers are deeply uncomfortable with giving customers free reign because of the possibility of unbridled and/or prolonged criticism (Li \& Bernoff, 2008; Weber, 2007). We therefore expect that the firm-managed community will be more likely to curb controversial or critical discussions, resulting in lower levels of expressive freedom. This discussion is summarized in the following hypothesis:

H10: (a) Expressive freedom and (b) demographic diversity will be greater and (c) psychographic diversity will be lower for the customer-managed when compared to the firmmanaged brand community.

Considerable prior research has shown that, in their interactions with marketers, consumers are aware of their persuasion attempts and know (or infer) when, where and how marketers will try to persuade them (e.g., Friestad \& Wright, 1994). Thus, participating in firm-sponsored brand communities is accompanied by the customer's understanding that the firm is in control of this venue and will attempt to persuade them, thus raising doubts about the community manager's motives. This is not only likely to make consumers trust the community to a lesser extent, in the sense that their beliefs about the community manager's benevolence, reliability, and integrity will be tempered, but they are also likely to identify with such a community to a lesser degree when compared to a customer-managed community, because of this cynicism and suspicion. Likewise, given traditional marketing concerns about giving exposure to competing brands, managers of the firm-managed community are unlikely to provide too much attention or editorial space to balanced discussions of competitor products. This leaves participants with more one-sided and incomplete information, rather than a complete picture of the product category. Consequently, learning is predicted to be lower in the firm-managed community. Therefore:

H11: (a) Community identification, (b) trust in the community manager, and (c) learning will be greater for the customer-managed when compared to the firm-managed brand community.

Under conditions where a group is relatively homogeneous on a particular dimension, individuals who are different along that dimension stand out (Saenz, 1994). In the present case, participants who perceive they are different from other members in the community are expected to have lower levels of trust and learn less. These effects should be more pronounced when the community is more homogeneous on that particular dimension, because the person's difference from others will become more salient to him or her (Saenz, 1994). 
Specifically, we expect the negative effects of demographic diversity on participants to be stronger in the firm-managed community, where its mean levels are expected to be lower. This should be manifested in stronger negative paths from demographic diversity to trust in the community manager and learning in the case of the firm-managed community, than for the customer-managed one. Similarly, the adverse effects of psychographic diversity are predicted to be more pronounced in the customer-managed community, which, on the whole, is less psychographically diverse. Therefore:

H12: The negative impacts of demographic diversity on (a) trust in community manager and (b) learning will be stronger for the firm-managed when compared to the customer-managed brand community.

H13: The negative impacts of psychographic diversity on (a) trust in community manager and (b) learning will be stronger for the customer-managed when compared to the firm-managed brand community.

Finally, we consider the different effects of expressive freedom on the firm-managed and customer-managed communities. Prior research has shown that, in industries where customer expectations are low, even providing average service has a significant positive impact on satisfaction (e.g., Oliver, 1980). Therefore, those participants who perceive higher expressive freedom in this setting should be more affected by it, resulting in their trusting the community manager more, and identifying with the community to a greater extent than participants of the customer-managed community. Thus:

H14: The positive impacts of expressive freedom on (a) community identification and (b) trust in community manager will be stronger for the firm-managed when compared to the customermanaged brand community.

\section{Method}

Research Setting. To test our proposed conceptual model we conducted an empirical study with active members of two XBOX brand communities in Brazil during the third quarter of 2008. The first, Portalxbox, is a customer-managed XBOX community, and the second, XBOX Brasil, is the sole company-managed XBOX community in the country.

Data from the Target Group Index, a report by IBOPE Media, indicate that $41 \%$ of residents in the main metropolitan areas in Brazil affirm they own a videogame console. In total, $31.5 \%$ of gamers are women and $68.5 \%$ are men, whereas $24.4 \%$ are between 25 and 34 years-old. Gamers from social classes AB comprise almost 50\%. In the US, similar market data are reported by the Entertainment Software Association (2011), indicating 34 as the average gamer age; also, 67\% of US households play videogames. Female players are growing in numbers: reports state that they already comprise $40 \%$ of all players, but this is a recent development. Moreover, this has happened mainly due to the introduction of Wii by Microsoft; women are not the main audience for the XBOX games analyzed in this study.

Portalxbox is currently the largest customer-managed XBOX brand community in Brazil with over 58,000 registered users and approximately 1,500 active users by the data collection period. The community was founded in October 2005 by three XBOX enthusiasts and is managed by them. Several interaction possibilities between members are available in the community, such as podcasts, reviews, several kinds of posts, etc. Community managers are nowadays Microsoft Most Valuable Professionals (MVPs).

XBOX Brasil was launched by Microsoft in June 2007, and had approximately 35,000 registered users and about 900 active users when the data collection took place. Three moderators, who are full-time Microsoft employees, manage it. 
Development of Measures. The measures employed in the study for community identification and brand relationship quality were derived from Algesheimer et al. (2005), and those for trust in the community manager and trust in the firm were adapted from Porter and Donthu (2008). We developed the measures for the remaining constructs using the following procedure advocated by Churchill (1979) and widely used by marketing researchers. First, we conducted in-depth interviews with 8 firmmanaged, and 9 customer-managed brand community managers, and approximately 30 participants of these brand communities in the US and Brazil. An initial set of items was generated from this exploratory research.

Next, to enhance the constructs' face validity, five additional community managers in the US (and one in Germany, well-versed in English) evaluated this item set. Items judged to be improperly worded were rephrased, and those not fitting the construct definition were deleted. Then, consumers belonging to a customer-managed brand community participated in a quantitative pre-test of the modified items. A few minor changes were made to the item wordings based on this feedback. An experienced translator translated the items into Portuguese. Finally, managers of Portalxbox and XBOX Brasil examined those items, and provided their feedback. The items for the study were finalized after incorporating this feedback. The full set of measurement items is presented in the Appendix.

Participant Recruitment. Participants for the study were recruited from amongst the active user base of the two communities in cooperation with the community managers. In both cases, links were provided to the questionnaire on the respective community's home-page inviting users to participate in a short survey. Potential participants had to log into their community account before being able to answer the survey. This restricted community non-members from answering and also prevented participants from responding to the survey more than once. Additionally, to prevent multiple responses from those consumers who belonged to both communities, they should provide their responses referring to the one in which they participated the most. In addition, managers of both communities encouraged participation by posting messages on the respective community's home page.

Respondent demographics are as follows. Among the 555 participants collaborating to the study virtually all are male (98.9\%). Respondents' ages ranged from under 18 to over 40 years old, concentrating mostly in the 18 to 25 range $(33.5 \%)$, and 26 to $30(27 \%)$. As for gross monthly household income, $22.4 \%$ made less than $\mathrm{R} \$ 3,000,39.2 \%$ made between $\mathrm{R} \$ 3,000$ and $\mathrm{R} \$ 7,500$, and $37.8 \%$ earned more than $\mathrm{R} \$ 7,500$. Respondents also reported a number of different professions.

Additionally, most of the study participants (72.9\%) have had online access for more than 7 years. Participants played XBOX games for 7.2 hours a week on average ( $\mathrm{SD}=10.7)$, and belonged to 1.83 XBOX communities on average $(\mathrm{SD}=.97)$. Finally, on average they had joined the respective brand communities 8.6 months prior to answering the survey $(\mathrm{SD}=6.3$ ).

Preliminary Analysis. Four constructs in the model - psychographic diversity, trust in community manager, community identification, and brand relationship quality - had more than two indicators. We employed the partial disaggregation approach (Bagozzi \& Edwards, 1998), combining indicators to produce two indicators each for those constructs. The remaining six constructs had two indicators each, which were used to operationalize them. All analyses were performed using covariance matrices. All of the constructs were operationalized as reflexive (Bollen \& Lennox, 1991; Edwards \& Bagozzi, 2000).

\section{Results}

\section{Measurement model evaluation}

Internal Consistency. We used two measures to evaluate construct internal consistency: 
composite reliability $\left(\rho_{\varepsilon}\right)$ (Bagozzi \& Yi, 1988; Fornell \& Larcker, 1981), and the average variance extracted (AVE; $\left.\rho_{\mathrm{VC}(\xi)}\right)$ (Fornell \& Larcker, 1981). Estimates for $\rho_{\varepsilon}$ above .60 and $\rho_{\mathrm{VC}(\xi)}$ above .50 are viewed as indicating good internal consistency (Bagozzi \& Yi, 1988; Fornell \& Larcker, 1981). The values found for all the constructs are significantly greater than those thresholds and are available upon request.

Convergent validity. We built a confirmatory factor analysis model with 10 latent constructs and 20 measures. Results showed that this model fit the data well. The model's goodness-of-fit statistics were as follows: $\chi^{2}(125)=217.2, \mathrm{p} \approx .00, \mathrm{RMSEA}=.03, \mathrm{SRMR}=.03$, NNFI $=.99, \mathrm{CFI}=$ .99. The standardized factor loadings ranged from .77 to 1.00 and were statistically significant at the $\alpha$ $=.95$ level. This provides evidence that the constructs exhibited convergent validity.

Discriminant validity. The first approach to examine discriminant validity was the procedure suggested by Fornell and Larcker (1981) and widely used by other researchers (e.g., Ramani \& Kumar, 2008). The AVE $\left(\rho_{\mathrm{VC}(\xi)}\right)$ for each of the ten factors was compared to the highest variance that the factor shared with other factors in the model. The AVE extracted for each factor was always greater than the highest shared variance, indicating the factors are discriminant. Nevertheless, we employed other two approaches to verify construct discriminant validity. As a second test we checked whether the correlations among the latent constructs were significantly less than one; this test provided additional assurance of discriminant validity (Bagozzi \& Yi, 1988). The correlation matrix is presented as an Appendix to the paper.

Third, we used a procedure suggested by Anderson and Gerbing (1988). We ran a series of nested confirmatory factor analyses in which we constrained the correlation between each pair of constructs to one. For all pairs (a total of 45 tests in all), when we compared the constrained model with a free one, the difference was significant, again suggesting that all of the construct measures achieve discriminant validity.

Common method variance. Since all of the survey measures were collected with a common instrument, there is a potential risk of a method bias. We used Harmon's one-factor test to assess whether a single latent factor could account for all manifest variables. This would indicate whether common method variance posed a serious threat to the interpretation of the findings from this study (Podsakoff, MacKenzie, Podsakoff, \& Lee, 2003). The single-factor model had a $\chi^{2}(170)=3367.9$. We performed a $\chi^{2}$-difference test against the 10 -factor measurement model to assess the impact of common method variance. A significant difference between the $\chi^{2}$ values of the two models $\left(\Delta \chi^{2}=\right.$ $3150.7, \Delta \mathrm{df}=45, \mathrm{p}<.001)$ indicated that the fit of the one-factor model was significantly worse than it was for the measurement model. This provides some evidence that the measurement model was robust to common method variance. Additionally, to confirm those results, we also employed the latent methods factor suggested by Podsakoff, MacKenzie, Podsakoff and Lee (2003). The results of this analysis are described in detail in the next section.

\section{Structural model estimation}

Our structural equation model $(\mathrm{SEM})$ includes all respondents $(\mathrm{N}=555)$ and was used to test the hypotheses. We ran all models described subsequently using LISREL 8.80 (Jöreskog \& Sörbom, 1999). Considering first the fit statistics for the full model hypothesized in Figure $1\left[\chi^{2}(150)=455.89\right.$, $\mathrm{p} \approx .00, \mathrm{RMSEA}=.06$, SRMR $=.08, \mathrm{NNFI}=.96$, and CFI $=.97]$, the $\chi^{2}$ is significant $(\mathrm{p}<.05)$; however, this is usually the case for large sample sizes like the one we have. All the other statistics are within the acceptable ranges, indicating a good model fit. Table 2 provides the standardized coefficients in the structural model. 
Table 2

Results of the Hypotheses Testing: Standardized Structural Model Coefficients

\begin{tabular}{|c|c|c|c|c|}
\hline \multirow[b]{2}{*}{ Path } & \multicolumn{2}{|c|}{ Full Sample $(N=555)$} & \multirow{2}{*}{$\begin{array}{c}N=336 \\
\begin{array}{c}\text { Consumer- } \\
\text { managed Sample }\end{array}\end{array}$} & \multirow{2}{*}{$\begin{array}{c}N=219 \\
\begin{array}{c}\text { Firm-managed } \\
\text { Sample }\end{array}\end{array}$} \\
\hline & $\begin{array}{l}\text { (Not controlling for } \\
\text { common method } \\
\text { variance) }\end{array}$ & $\begin{array}{l}\text { (Controlling for } \\
\text { common method } \\
\text { variance) }\end{array}$ & & \\
\hline $\mathrm{L} \rightarrow \mathrm{TCM}$ & $.37 * * *$ & $.49 * * *$ & $.38 * * *$ & $.48 * * *$ \\
\hline $\mathrm{TCM} \rightarrow \mathrm{CI}$ & $.26^{* * *}$ & $.37 * * *$ & $.23 * * *$ & $.36 * * *$ \\
\hline $\mathrm{DD} \rightarrow \mathrm{TCM}$ & $-.12^{*}$ & $-.11 *$ & -.00 & $-.33 * * *$ \\
\hline $\mathrm{DD} \rightarrow \mathrm{L}$ & -.05 & -.00 & -.12 & .04 \\
\hline $\mathrm{PD} \rightarrow \mathrm{TCM}$ & $-.29 * * *$ & $-.32 * * *$ & $-.41 * * *$ & -.04 \\
\hline $\mathrm{PD} \rightarrow \mathrm{L}$ & $-.13^{*}$ & $-.11 *$ & $-.18^{*}$ & -.04 \\
\hline $\mathrm{EF} \rightarrow \mathrm{CI}$ & $.10^{*}$ & $.08^{*}$ & .08 & $.49^{* * *}$ \\
\hline $\mathrm{EF} \rightarrow \mathrm{TCM}$ & .04 & -.03 & -.04 & $.13^{*}$ \\
\hline $\mathrm{CI} \rightarrow \mathrm{BRQ}$ & $.23 * * *$ & $.44 * * *$ & .11 & $.67 * * *$ \\
\hline $\mathrm{TCM} \rightarrow \mathrm{BRQ}$ & $.28 * * *$ & $.47 * * *$ & $.25 * *$ & $.32 * * *$ \\
\hline $\mathrm{CI} \rightarrow \mathrm{CIBD}$ & $.13 *$ & $.48 * * *$ & .10 & $.57 * * *$ \\
\hline $\mathrm{TCM} \rightarrow \mathrm{CIBD}$ & $.31 * * *$ & $.70 * * *$ & $.40 * * *$ & $.27 * * *$ \\
\hline $\mathrm{BRQ} \rightarrow \mathrm{CIBD}$ & $.60 * * *$ & $.49 * * *$ & $.49 * * *$ & $.39 * * *$ \\
\hline $\mathrm{CI} \rightarrow \mathrm{TF}$ & $.21 * * *$ & $.50 * * *$ & .07 & $.38 * * *$ \\
\hline $\mathrm{TCM} \rightarrow \mathrm{TF}$ & $.15^{* *}$ & $.49 * * *$ & .11 & $.23 * * *$ \\
\hline $\mathrm{BRQ} \rightarrow \mathrm{TF}$ & $.52 * * *$ & $.39 * * *$ & $.54 * * *$ & .01 \\
\hline $\mathrm{BRQ} \rightarrow \mathrm{OL}$ & $.73 * * *$ & $.62 * * *$ & $.67 * * *$ & $.62 * * *$ \\
\hline $\mathrm{L} \rightarrow \mathrm{OL}$ & .05 & -.06 & .07 & .05 \\
\hline
\end{tabular}

Note. $* \mathrm{p}<.05 . * * \mathrm{p}<.01 . * * * \mathrm{p}<.001$.

Considering the impact of learning on trust in the community manager first, as expected it shows a strong positive impact $(\beta=.37, \mathrm{p}<.001)$, supporting H1. Also as predicted, trust in the community manager impacts community identification significantly $(\beta=.26, p<.001)$, providing support for H2. As expected, demographic diversity has a significant negative impact on trust in the community manager $(\gamma=-.12, p<.05)$, but its effect on learning is not significant $(\gamma=-.05$, ns). Thus, $\mathrm{H} 3 \mathrm{a}$ receives support, but $\mathrm{H} 3 \mathrm{~b}$ is not supported. Furthermore, as predicted, psychographic diversity has a negative impact on trust in the community manager $(\gamma=-.29, p<.001)$ and learning $(\gamma=-.13, p$ $<.05$ ), providing support for $\mathrm{H} 4 \mathrm{a}$ and $\mathrm{H} 4 \mathrm{~b}$ respectively. Considering $\mathrm{H} 5 \mathrm{a}-\mathrm{b}$, expressive freedom has a significant positive impact on community identification $(\gamma=.10, p<.05)$, but its impact on trust in community manager is not significant $(\gamma=.04$, ns). Thus H5a is supported, but H5b is not. The percentages of variance in community identification, trust in the community manager and learning explained by their respective antecedents were $38 \%, 70 \%$ and $86 \%$, respectively.

The remaining main effect hypotheses concern the effects of the mediating variables on to the outcome variables. First, considering effects of antecedents on brand relationship quality, both community identification $(\beta=.23, \mathrm{p}<.001)$, and trust in the community manager $(\beta=.28, \mathrm{p}<.001)$ positively impact brand relationship quality, supporting H6a and H6b. $87 \%$ of the variance in brand relationship quality was explained by the antecedents. Also as expected, community identification $(\beta=$ $.13, \mathrm{p}<.05)$, trust in the community manager $(\beta=.31, \mathrm{p}<.001)$, and brand relationship quality $(\beta=$ 
$.60, \mathrm{p}<.001)$ each significantly impact the community's influence on buying decisions, thus supporting H7a-c, and explaining $61 \%$ of its variance. Considering the impact of antecedents on trust in the firm hypothesized in H8a-c next, we find that all three hypotheses are supported, because the effects of community identification $(\beta=.21, \mathrm{p}<.001)$, trust in the community manager $(\beta=.15, \mathrm{p}<$ $.01)$, and brand relationship quality $(\beta=.52, \mathrm{p}<.001)$ on trust in the firm are significant. $57 \%$ of the variance in trust in the firm is explained by the antecedents Finally, H9a-b hypothesized positive impacts of learning and brand relationship quality on oppositional loyalty. Results showed that learning did not have a significant path $(\beta=.05$, ns), but the impact of brand relationship quality was significant $(\beta=.73, \mathrm{p}<.001)$. Thus, H9a does not receive support, but H9b is supported. $46 \%$ of the variance in oppositional loyalty was explained.

Results of latent methods factor approach. To further rule out the effects of common method bias, we employed Podsakoff and colleagues' (2003) latent methods factor approach. Using this approach, all measures in the structural model hypothesized in Figure 1 were loaded onto a single latent factor in addition to their respective factors. This additional factor is the common methods factor, allowing us to control for the portion of the variance that is attributable to gathering all the measures with the same method. The results of this re-estimation are provided in the third column of Table 2. Note that in this new model, equality constraints were imposed on the loadings from the methods factor to its indicators to obtain convergence. As can be seen, overall the results are substantively similar, whether or not the common method variance is controlled for, indicating that the pattern of significant relationships was not affected significantly by common method bias.

\section{Moderating influences of community management}

We conducted multiple sample analyses (Jöreskog \& Sörbom, 1999) for the firm-managed and customer-managed community sub-samples to examine the moderating role of community manager. We then determined whether the differences in the factor means between the groups were significantly different from each other. Table 3 provides the results.

Table 3

Tests of Factor Mean Differences between Customer-Managed and Firm-Managed Community Sub-Samples

\begin{tabular}{lccc}
\hline \multicolumn{1}{c}{ Constructs } & $\begin{array}{c}\text { Customer- } \\
\text { Managed Comm. } \\
\text { Factor Mean }\end{array}$ & $\begin{array}{c}\text { Firm-Managed } \\
\text { Community } \\
\text { Factor Mean }\end{array}$ & $\begin{array}{c}\text { t-value, significance } \\
\text { level }\end{array}$ \\
\hline Expressive freedom & $0 /(9.49)^{\mathbf{a}}$ & $-.75 /(8.56)$ & $-4.79, p<.001$ \\
Demographic diversity & $0 /(8.16)$ & $-.43 /(7.28)$ & $-3.22, p<.01$ \\
Psychographic diversity & $0 /(12.01)$ & $.36 /(11.47)$ & $2.93, p<.01$ \\
Community identification & $0 /(15.26)$ & $-1.34 /(11.54)$ & $-9.03, p<.001$ \\
Trust in community manager & $0 /(18.08)$ & $-1.49 /(13.68)$ & $-14.45, p<.001$ \\
Learning & $0 /(12.18)$ & $-1.50 /(9.03)$ & $-10.70, p<.001$ \\
Community's influence on buying decisions & $0 /(10.54)$ & $-1.20 /(8.16)$ & $-7.41, p<.001$ \\
Trust in the firm & $0 /(7.26)$ & $.63 /(8.48)$ & $4.10, p<.001$ \\
Brand relationship quality & $0 /(21.23)$ & $.06 /(21.18)$ & $.44, n s$ \\
Oppositional loyalty & $0 /(6.89)$ & $.13 /(7.13)$ & $.71, n s$ \\
\hline
\end{tabular}

Note. ${ }^{a}$ Values in parentheses are summed scale means for the sub-sample.

The results in Table 2 show that, when compared to customer-managed communities, participants in firm-managed communities report lower levels of expressive freedom and demographic 
diversity, but higher levels of psychographic diversity. These results support H10. The levels of community identification, trust in community manager, and learning are all lower for firm-managed communities, thus supporting H11. Interestingly, although we did not have specific hypotheses, the factor mean for trust in the firm was higher for the firm-managed community when compared to the customer-managed community, although it did not influence participants' buying decisions as much. The levels of brand relationship quality and oppositional loyalty were not statistically different for the two groups.

To test H12, H13, and H14, we built separate structural models for the firm-managed and customer-managed community sub-samples, and then conducted tests of moderation using multiple sample analysis via LISREL to determine whether the respective path coefficients differed from one another. Table 4 summarizes the analyses and results.

Table 4

Results of Multiple Sample Analyses to Test H12, H13, and H14: Firm-Managed vs. CustomerManaged Community Sub-Samples

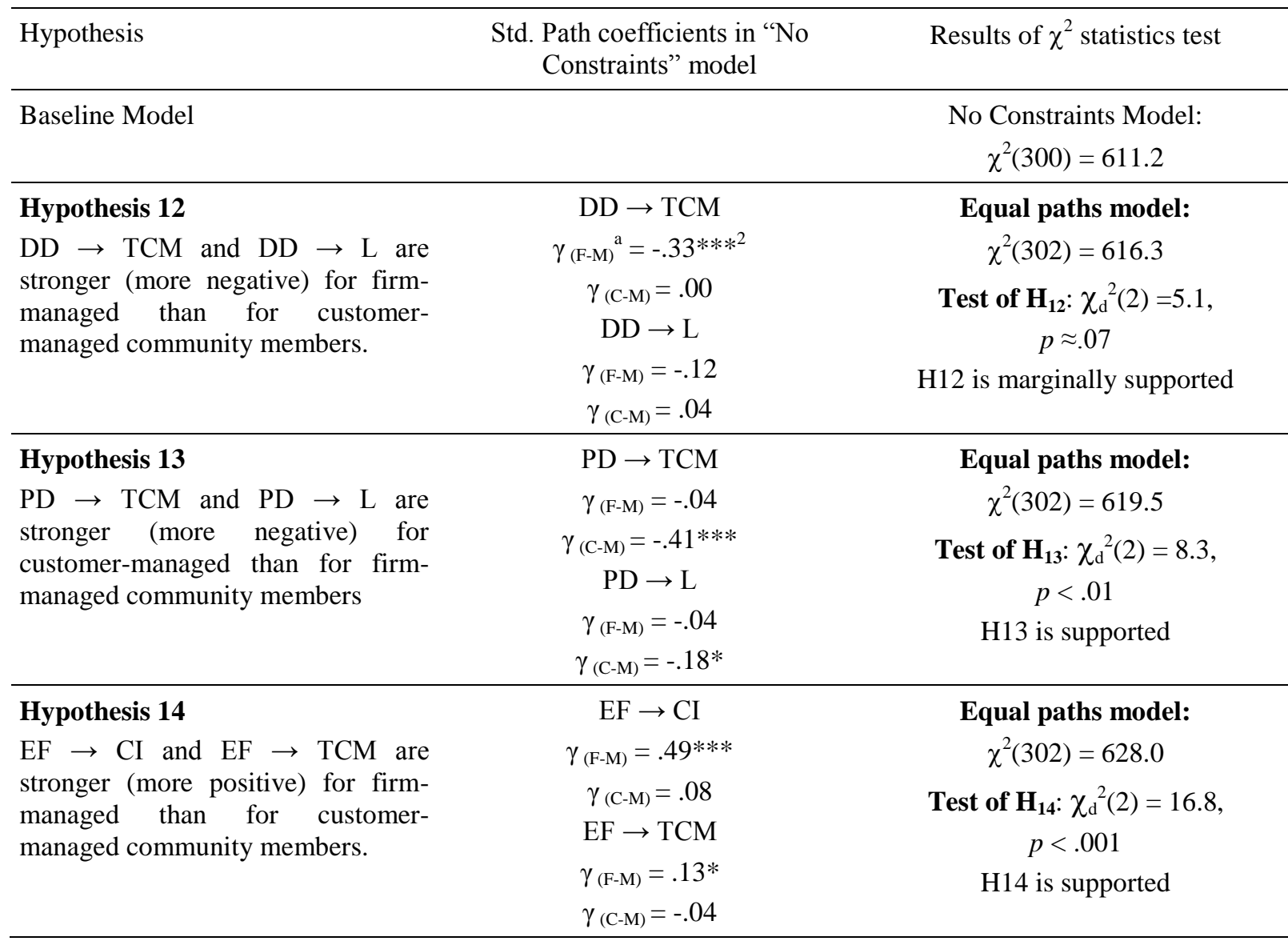

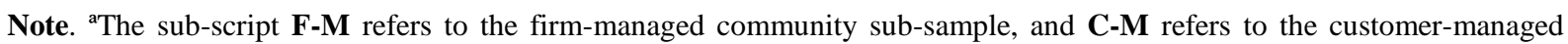
community sub-sample.

$* p<.05 . * * p<.01 . * * * p<.001$.

The procedure that we used was as follows for each test: We constructed two multiple-sample models. In the first model, all paths were unconstrained between the two groups. This is the no constraints or the baseline model in Table 3. In the second model, we constrained the relevant paths (e.g., DD $\rightarrow \mathrm{TCM}$ and $\mathrm{DD} \rightarrow \mathrm{L}$ in the case of H12) to be equal for both sub-samples. This is the equal paths model. The difference in chi-square values between the two models provides a test for the equality of the paths for the two communities. 
Consider the first row of Table 3 in the light of this procedure. Results reveal that the DD $\rightarrow$ $\mathrm{TCM}$ and the $\mathrm{DD} \rightarrow \mathrm{L}$ paths are stronger (more negative) for the firm-managed than for the customermanaged community at the $\mathrm{p} \approx .07$ level. Thus, H12 is marginally supported. As Table 3 also shows, $\mathrm{H} 13$ and $\mathrm{H} 14$ are supported. As $\mathrm{H} 13$ predicted, the paths from $\mathrm{PD} \rightarrow \mathrm{TCM}$ and $\mathrm{PD} \rightarrow \mathrm{L}$ were stronger (more negative) for the customer-managed community. In contrast the paths from $\mathrm{EF} \rightarrow \mathrm{CI}$ and $\mathrm{EF} \rightarrow$ TCM were stronger (more positive in this case) for the firm-managed community $(p<.001)$ in support of H14. We find the hypothesized differences in the effects of psychographic diversity when compared to demographic diversity and expressive freedom for firm-managed and customer-managed brand communities. The levels of expressive freedom and demographic diversity are lower, yet their respective effects are stronger in the firm-managed community, whereas psychographic diversity is lower, but it has negative effects in the customer-managed community.

\section{Discussion and Implications}

In the current research, we studied the effects of participant diversity and expressive freedom on trust, learning, and identification in brand communities along with their effects on firm-relevant outcomes, and examined differences between firm-managed and customer-managed communities. Information regarding how these variables affect the brand community's effectiveness is critical for its managers in making decisions regarding which consumers to target and how much control to exert in moderating community discussions. Our results showed that participant diversity and expressive freedom have mixed effects. Demographic and psychographic diversity hindered participants' learning and their trust in the community's manager whereas we found expressive freedom to be beneficial in fostering community identification, even though it did not impact trust perceptions. These findings suggest that the composition of the brand community does matter, and that brand community managers should take participant diversity into account and attempt to determine and manage it in their communities. On the other hand, controlling participants' communications may not pay, especially for firm-managed brand communities, according to our results.

In our analysis, trust in the community's manager was also affected by how much participants learned about the product category from the community, and trust, in turn, affected community identification. Our results also revealed that trust in the community manager and community identification influenced the quality of the relationship between participants and the XBOX brand, the community's influence on their buying decisions, and their trust in the firm. Finally, we found brand relationship quality to have significant positive effects on the community's influence in buying decisions, trust in the firm, and oppositional loyalty. These results shed light on the processes through which brand community interactions produce relevant positive outcomes for the brand and the firm.

In comparing the firm-managed and customer-managed brand communities, we found a number of differences. The levels of expressive freedom, community identification, trust in the community manager, perceptions of having learned about the product category, and the community's influence on buying decisions were all significantly lower in the Microsoft-managed community when compared to the community that was managed by XBOX enthusiasts. These results bring to light an interesting paradox about brand communities, which is that many of the more favorable effects for Microsoft occur in the brand community that it does not directly control, but which has been founded and is managed by its customers. Our findings, and this paradox, have several important implications for marketing managers. They offer reassurance to those firms that currently do not have their selfmanaged brand community but have vibrant customer-managed communities in existence.

Even if firms already have functioning self-managed brand communities, they might benefit from offering low-key support to their customer-managed communities. For example, in Brazil, Microsoft recently started to provide a physical meeting space, offering food, audio-visual equipment, utilities, and so on, for periodic face-to-face meetings for members of Portalxbox, the customermanaged community. 
Our findings regarding the effects of participant diversity also provide useful guidelines for brand community managers. Overall, the effects of demographic and psychographic diversity on the mediating variables in our conceptual framework were negative. However, the results were different in the two brand communities. We found the community managed by Microsoft to be more demographically homogeneous (as perceived by its members), yet the adverse effects of perceived demographic diversity on trust in the community's manager, as well as learning, were stronger. The results were the opposite for the customer-managed community sample. In this community, participants perceived themselves to be psychographically more similar to one another, but perceptions of greater psychographic diversity led to lower trust and learning from the community interactions.

Community composition is determined by customers choosing to join a particular community (Algesheimer \& Dholakia, 2006). It is possible that demographically similar participants join the firmmanaged community, and psychographically similar participants prefer the customer-managed community to a greater extent. Not surprisingly, both groups feel comfortable interacting with others who are similar to them. However, understanding why customers choose membership in this fashion is important. It could be that the firms provide content and functionality within their online community venues, and events and programs for participants' face-to-face interactions that they deem more suitable for their target customers (McAlexander et al., 2002). In contrast, customer-managed communities may be more likely to be formed by customer demographic groups that the firm has overlooked, which although varying in demographic characteristics, are more homogeneous in their values, interests, and hobbies. If such is the case, then customer-managed communities may actually expand the coverage and scope of brand communities to more audiences than the firm itself focuses on, and may even help firms identify neglected consumer groups that are interested in their brands. Further research is needed to shed light on this possibility.

Another decision variable that may moderate the effects of diversity, and which is important to the community manager, is the role of brand community size. In the present research, both communities were quite large, having hundreds of active members. It is important for future research to examine the effects of overall community size and also the prevalence and effects of smaller affinity groups within the community (Bagozzi \& Dholakia, 2006b).

Despite the study's contributions, it does have some limitations. One is that we employed a survey methodology in which the measures were gathered at a single time. To counter this weakness, we employed a number of analytical approaches such as establishing construct discriminant validity and perhaps more importantly, using Harmon's one-factor test and Podsakoff and colleagues' (2003) latent factor approach to evaluate the effects of common method bias. All of these analyses consistently provided evidence of no significant adverse impact of using the common method. Nevertheless, the results must be interpreted with caution.

Another limitation is that although the use of Brazilian respondent samples is novel and extends the study of brand communities to a new nationality, it does demand caution when extrapolating these findings to consumers from other countries. Still, we have no reason to expect significant cultural differences between Brazilian XBOX customers and those from other countries. Nevertheless, one must take into consideration that the present study examined only one product category and its leading brand, even though the product is of the high involvement kind and thus very suitable for theoretical investigation. The communities analyzed are also more organized and structured than the average consumer communities found online, which is also a limitation for generalizations, regardless of their higher involvement and increasing participation. Another limit refers to the sample being comprised mostly of male respondents and people under 30 years-old. We also have no reason to believe that the respondents from the two main Brazilian communities have different profiles from the general XBOX gamer population, but as no official statistics are available on XBOX users in Brazil, care must be taken with generalizations once more.

In conclusion, our present findings help positioning brand communities as effective marketing programs within the tool-box available for marketing managers, and provide new and useful insights 
into answering key questions concerning the roles of participant diversity and expressive freedom in firm-managed and customer-managed brand communities.

\section{References}

Adjei, M. T., Noble, S. M., \& Noble, C. H. (2010). The influence of C2C communications in online brand communities on customer purchase behavior. Journal of the Academy of Marketing Science, 38(5), 634-653. doi: 10.1007/s11747-009-0178-5

Agustin, C., \& Singh, J. (2005). Curvilinear effects of consumer loyalty determinants in relational exchanges. Journal of Marketing Research, 42(1), 96-108. doi: 10.1509/jmkr.42.1.96.56961

Algesheimer, R., \& Dholakia, P. M. (2006). Do customer communities pay off? Harvard Business Review, 84(11), 26-30.

Algesheimer, R., Dholakia, U. M., \& Herrmann, A. (2005). The social influence of brand community: evidence from European car clubs. Journal of Marketing, 69(3), 19-34. doi: 10.1509/jmkg.69.3.19.66363

Anderson, J. C., \& Gerbing, D. W. (1988). Structural equation modeling in practice: a review and twostep approach. Psychological Bulletin, 103(3), 411-423. doi: 10.1037//0033-2909.103.3.411

Bagozzi, R. P., \& Dholakia, U. M. (2002). Intentional social action in virtual communities. Journal of Interactive Marketing, 16(2), 2-21. doi: 10.1002/dir.10006

Bagozzi, R. P., \& Dholakia, U. M. (2006b). Antecedents and purchase consequences of customer participation in small group brand communities. International Journal of Research in Marketing, 23(1), 45-61. doi: 10.1016/j.ijresmar.2006.01.005

Bagozzi, R. P., \& Dholakia, U. M. (2006a). Open source software user communities: a study of participation in linux user groups. Management Science Special Issue, 52(7), 1099-1115. doi: $10.1287 / \mathrm{mnsc} .1060 .0545$

Bagozzi, R. P., Dholakia, U. M., \& Pearo, L. R. K. (2007). Antecedents and consequences of online social interactions. Media Psychology, 9(1), 77-114. doi: 10.1080/15213260709336804

Bagozzi, R. P., \& Edwards, J. R. (1998). A general approach for representing constructs in organizational research. Organizational Research Methods, 1(1), 45-87. doi: $10.1177 / 109442819800100104$

Bagozzi, R. P., \& Yi, Y. (1988). On the evaluation of structural equation models. Journal of the Academy of Marketing Science, 16(1), 74-94. doi: 10.1007/BF02723327

Berthon, P., Pitt, L., \& Campbell, C. (2008). Ad lib: when customers create the ad. California Management Review, 50(4), 6-30. doi: 10.1080/14622200802123302

Bollen, K., \& Lennox, R. (1991). Conventional wisdom on measurement: a structural equation perspective. Psychological Bulletin, 110(2), 305-314. doi: 10.1037//0033-2909.110.2.305

Casaló, L., Flavián, C., \& Guinalíu, M. (2007). The impact of participation in virtual brand communities on consumer trust and loyalty: the case of free software. Online Information Review, 31(6), 775-792. doi:10.1108/14684520710841766

Churchill, G. A., Jr. (1979). A paradigm for developing better measures of marketing constructs. Journal of Marketing Research, 16(1), 64-73. doi: 10.2307/3150876 
Cova, B., \& Cova, V. (2002). Tribal marketing: the tribalisation of society and its impact on the conduct of marketing. European Journal of Marketing, 36(5/6), 595-620. doi: $10.1108 / 03090560210423023$

Davis, J. H., Schoorman, F. D., Mayer, R. C., \& Tan, H. H. (2000). The trusted general manager and business unit performance: empirical evidence of a competitive advantage. Strategic Management Journal, 21(5), 563-576. doi: 10.1002/(SICI)1097-0266(200005)21:5<563::AIDSMJ99>3.0.CO;2-0

Dholakia, U. M., Bagozzi, R. P., \& Pearo, L. K. (2004). A social influence model of consumer participation in network-and small-group-based virtual communities. International Journal of Research in Marketing, 21(3), 241-263. doi: 10.1016/j.ijresmar.2003.12.004

Dholakia, U. M., Blazevic, V., Wiertz, C., \& Algesheimer, R. (2009). Communal service delivery: how customers benefit from participation in firm-hosted virtual P3 communities. Journal of Service Research, 12(2), 208-226. doi: 10.1177/1094670509338618

DiTomaso, N., Post, C., \& Parks-Yancy, R. (2007). Workforce diversity and inequality: power, status, and numbers. Annual Review of Sociology, 33, 473-501. doi: 10.1146/annurev.soc.33.040406.131805

Donath, J. S. (1999). Identity and deception in the virtual community. In M. A. Smith \& P. Kollock (Eds.), Communities in cyberspace (pp. 29-59). London: Routledge.

Edwards, J. R., \& Bagozzi, R. P. (2000). On the nature and direction of relationships between constructs and measures. Psychological Methods, 5(2), 155-174. doi: 10.1037//1082989X.5.2.155

Entertainment Software Association. (2011). 2011 Essential facts about the computer and video game industry. Retrieved from http://www.theesa.com/facts/pdfs/ESA_EF_2011.pdf

Flavián, C., \& Guinalíu, M. (2005). The influence of virtual communities on distribution strategies in the internet. International Journal of Retail \& Distribution Management, 33(6), 405-425. doi: $10.1108 / 09590550510600843$

Fornell, C., \& Larcker, D. F. (1981). Evaluating structural equation models with unobservable variables and measurement error. Journal of Marketing Research, 18(1), 39-50. doi: $10.2307 / 3151312$

Friestad, M., \& Wright, P. (1994). The persuasion knowledge model: how people cope with persuasion attempts. Journal of Consumer Research, 21(1), 1-31.

GFK Consumer Choices Report. (2012, Aug. 24). Consumer choices report. Retrieved from http://www.uol.com.br

IBOPE Media. (2012). Target group index. Retrieved from http://www.ibope.com.br/ptbr/noticias/Paginas/Conheca-as-caracteristicas-de-quem-joga-videogame-no-Brasil.aspx

Jöreskog, K., \& Sörbom, D. (1999). LISREL 8: user's reference guide (2nd ed.). Illinois: Scientific Software International.

Koriat, A. (1993). How do we know that we know? The accessibility model of the feeling of knowing. Psychological Review, 100(4), 609-639. doi: 10.1037/0033-295X.100.4.609

Kozinets, R. V. (2006). Click to connect: netnography and tribal advertising. Journal of Advertising Research, 46(3), 279-288. doi: 10.2501/S0021849906060338 
Li, C., \& Bernoff, J. (2008). Groundswell: winning in a world transformed by social technologies. Boston: Harvard Business School Press.

Mackie, D. M., Devos, T., \& Smith, E. R. (2000). Intergroup emotions: explaining offensive action tendencies in an intergroup context. Journal of Personality and Social Psychology, 79(4), 602616. doi: 10.1037/0022-3514.79.4.602

Mathwick, C., Wiertz, C., \& Ruyter, K. de (2008). Social capital production in a virtual p3 community. Journal of Consumer Research, 34(6), 832-849. doi: 10.1086/523291

McAlexander, J. H., Schouten, J. W., \& Koenig, H. F. (2002). Building brand community. Journal of Marketing, 66(1), 38-54. doi: 10.1509/jmkg.66.1.38.18451

McKay, P. F., \& McDaniel, M. A. (2006). A reexamination of black-white mean differences in work performance: more data, more moderators. Journal of Applied Psychology, 91(3), 538-554. doi: 10.1037/0021-9010.91.3.538

Mitchell, V. (1999). Consumer perceived risk: conceptualizations and models. European Journal of Marketing, 33(1/2), 163-195. doi: 10.1108/03090569910249229

Morgan, R. M., \& Hunt, S. D. (1994). The commitment-trust theory of relationship marketing. Journal of Marketing, 58(3), 20-38. doi: 10.2307/1252308

Muñiz, A. M., Jr., \& Hamer, L. O. (2001). Us versus them: oppositional brand loyalty and the cola wars. Advances in Consumer Research, 28(1), 355-361.

Muñiz, A. M., Jr., \& O'Guinn, T. C. (2001). Brand community. Journal of Consumer Research, 27(4), 412-432. doi: 10.1086/319618

Muñiz, A. M., Jr., \& Schau, H. J. (2005). Religiosity in the abandoned apple newton brand community. Journal of Consumer Research, 31(4), 737-747. doi: 10.1086/426607

Muñiz, A. M., Jr., \& Schau, H. J. (2007). Vigilante marketing and consumer-created communications. Journal of Advertising, 36(3), 35-50. doi: 10.2753/JOA0091-3367360303

Oliver, R. L. (1980). A cognitive model of the antecedents and consequences of satisfaction decisions. Journal of Marketing Research, 17(4), 460-469.

Ouwersloot, H., \& Odekerken-Schröder, G. (2008). Who's who in brand communities - and why? European Journal of Marketing, 42(5/6), 571-585. doi: 10.1108/03090560810862516

Palmatier, R. W., Dant, R. P., Grewal, D., \& Evans, K. R. (2006). Factors influencing the effectiveness of relationship marketing: a meta-analysis. Journal of Marketing, 70(4), 136-153. doi: 10.1509/jmkg.70.4.136

Podsakoff, P. M., MacKenzie, S. B., Podsakoff, N. P., \& Lee, J. (2003). Common method biases in behavioral research: a critical review of the literature and recommended remedies. Journal of Applied Psychology, 88(5), 879-903. doi: 10.1037/0021-9010.88.5.879

Porter, C. E., \& Donthu, N. (2008). Cultivating trust and harvesting value in virtual communities. Management Science, 54(1), 113-128. doi:10.1287/mnsc.1070.0765

PricewaterhouseCoopers. (2011). Global gaming outlook: the casino and online gaming market to 2015. Retrieved from http://www.pwc.com/gx/en/entertainment-media/publications/globalgaming-outlook.jhtml

Ramani, G., \& Kumar, V. (2008). Interaction orientation and firm performance. Journal of Marketing, 72(1), 27-45. doi: 10.1509/jmkg.72.1.27 
Ridings, C. M., Gefen, D., \& Arinze, B. (2002). Some antecedents and effects of trust in virtual communities. Journal of Strategic Information Systems, 11(3/4), 271-295. doi: 10.1016/s09638687(02)00021-5

Saenz, D. S. (1994). Token status and problem-solving deficits: detrimental effects of distinctiveness and performance monitoring. Social Cognition, 12(1), 61-74.

Schlosser, A. E., White, T. B., \& Lloyd, S. M. (2006). Converting website visitors into buyers: how website investment increases consumer trusting beliefs and online purchase intentions. Journal of Marketing, 70(2), 133-148. doi: 10.1509/jmkg.70.2.133

Schouten, J. W., \& McAlexander, J. H. (1995). Subcultures of consumption: an ethnography of the new bikers. Journal of Consumer Research, 22(1), 43-61. doi: 10.1086/209434

Stokburger-Sauer, N. (2010). Brand community: drivers and outcomes. Psychology and Marketing, 27(4), 347-368. doi: 10.1002/mar.20335

Tajfel, H., \& Turner, J. C. (1986). The social identity theory of intergroup behavior. In S. Worchel \& L. W. Austin (Eds.), Psychology of intergroup relations (pp. 7-24). Chicago: Nelson-Hall.

Thompson, S. A., \& Sinha, R. K. (2008). Brand communities and new product adoption: the influence and limits of oppositional loyalty. Journal of Marketing, 72(6), 65-80. doi: 10.1509/jmkg.72.6.65

Turner, J. C. (1987). Rediscovering the social group: a self-categorization theory. New York: Basil Blackwell.

Weber, L. (2007). Marketing to the social web: how digital customer communities build your business. Hoboken, New Jersey: John Wiley \& Sons.

Zellmer-Bruhn, M. E., Maloney, M. M., Bhappu, A. D., \& Rommel (Bombie) S. (2008). When and how do differences matter? An exploration of perceived similarity in teams. Organizational Behavior and Human Decision Processes, 107(1), 41-59. doi: 10.1016/j.obhdp.2008.01.004 


\section{APPENDIX}

Table A1

\section{Summary of Constructs and Their Measures (English Versions of Measures)}

\section{Expressive freedom (Two measures)}

- In [Community], we can discuss any topic that is of interest to the members.

- There are no restrictions regarding the topics we can talk about in [Community].

\section{Psychographic diversity (Three measures)}

- Other [Community] members and I share the same values. (Reverse)

- I think the members of [Community] are very similar in their interests and hobbies. (Reverse)

a. I have the same outlook on life as most other [Community] members do. (Reverse)

\section{Demographic diversity (Two measures)}

- I find other members in [Community] to be similar to me in demographic characteristics such as age, income, gender, and profession. (Reverse)

- [Community] does not seem to have a lot of diverse participants in demographic characteristics.

\section{Trust in community manager (Three measures)}

- I trust the information that I find in [Community].

- The [Community]'s managers are trustworthy.

○ The moderators of [Community] have the best interests of their members in mind.

\section{Learning (Two measures)}

- I learn a lot of new information regarding video and online games from participating in [Community].

- I have acquired a lot of video and online game-related knowledge in [Community].

\section{Community identification (Three measures)}

- I perceive myself to be part of [Community].

- I have meet wonderful people thanks to this brand community.

- The image that I have formed of myself fits perfectly with the [Community]'s identity.

\section{Community influence on buying decisions (Two measures)}

- [Community] has a lot of influence in the way I take my buying decisions regarding video and online games.

- This community has a lot of influence in my opinions about this brand.

\section{Trust in the firm (Two measures)}

- Microsoft (the parent company that owns the XBOX brand) cares for the welfare of its customers, as well as its own, when making important decisions.

- I trust Microsoft (the parent company that owns the XBOX brand).

\section{Brand relationship quality (Five measures)}

- I feel emotionally attached to the XBOX brand.

- The XBOX brand has an important role in my life.

- The XBOX brand's image and my image are similar in many respects.

- I feel a strong sense of identification with the XBOX brand.

- This brand says a lot about the kind of person I am.

\section{Oppositional loyalty (Two measures)}

- I consider Nintendo and Sony Playstation games to be inferior to XBOX games.

- I'm always trying to convince my friends to not play Nintendo or Sony Playstation games. 
Table A2

Correlation Matrix of Constructs in Theoretical Framework for Full Sample ( $N=555)$

\begin{tabular}{lcccccccccc}
\hline & EF & PD & DD & CI & TCM & L & CIBD & TF & BRQ & OL \\
\hline EF & 1 & & & & & & & & & \\
PD & -.24 & 1 & & & & & & & & \\
DD & -.01 & .45 & 1 & & & & & & & \\
CI & .33 & -.51 & -.02 & 1 & & & & & & \\
TCM & .35 & -.34 & .03 & .66 & 1 & & & & & \\
L & .27 & -.33 & .08 & .69 & .58 & 1 & & & & \\
CIBD & .23 & -.44 & .02 & .70 & .58 & .71 & 1 & & & \\
TF & .08 & -.16 & -.16 & .19 & .19 & .09 & .17 & 1 & & \\
BRQ & .12 & -.35 & -.14 & .43 & .31 & .16 & .30 & .44 & 1 & \\
OL & .09 & -.28 & -.12 & .24 & .15 & .12 & .26 & .31 & .52 & 1 \\
\hline
\end{tabular}

Note. *All coefficients are significant at $\alpha=.05$ level; All correlations are significantly less than 1.00; EF: Expressive freedom; PD: Psychographic diversity; DD: Demographic diversity; CI: Community identification; TCM: Trust in community manager; L: Learning; CIBD: Community influence in buying decisions; TF: Trust in the firm; BRQ: Brand relationship quality; OL: Oppositional loyalty 